\title{
EVALUATION OF THE WOUND HEALING PROPERTIES OF METHANOLIC BARK EXTRACT OF SAMADERA INDICA GAERTNER IN VIVO
}

\author{
DEEPA PR ${ }^{1}$, RAMA BHAT ${ }^{1 *}$, RAVI RAO $S^{2}$ \\ ${ }^{1}$ Department of Biotechnology, Alva's College, Moodbidri, Karnataka, India. ${ }^{2}$ Department of Dravyaguna, Alva's Ayurveda Medical \\ College, Moodbidri, Karnataka, India. Email: nhat_pr@rediffmail.com
}

Received: 05 March 2019, Revised and Accepted: 11 April 2019

\section{ABSTRACT}

Objective: The present study was conducted to evaluate the effect of Samadera indica bark extracts on experimentally induced excision wounds in Wistar rats.

Methods: The bark samples were collected, allowed to shade dry for a week, then coarsely powdered and were extracted with methanol by the soxhlation process. The extract was used for wound healing experiment using the excision wound model. 18 healthy Wistar albino rats divided into three groups of six rats each with an average body weight of 150-200 g were selected randomly for the study. ANOVA was used to compare the variation in the treatments in the result. The $1^{\text {st }}$ group of animals is left as such for the natural healing process as control, $2^{\text {nd }}$ group of animals was treated with standard ointment betadine, and $3^{\text {rd }}$ group with the test drug methanolic bark ointment formulation. The methanolic extract in simple ointment base as mentioned above and betadine ointment were applied on the wound once a day for 16 days starting from the day of wounding. The percentage of wound closure was observed on $4^{\text {th }}, 8^{\text {th }}, 12^{\text {th }}$, and $16^{\text {th }}$ post-wounding day.

Results: As for the group received methanolic bark extract for wound healing, $4^{\text {th }}$-day wound mean diameter was $208.0 \pm 3.521,8^{\text {th }}$-day the wound mean diameter was $160.66 \pm 7.89,12^{\text {th }}$-day wound mean diameter was $87.5 \pm 5.8$, and $16^{\text {th }}$-day wound mean diameter was $22.5 \pm 5.12$. Thus, there was a marked decrease in wound diameter with every point of time the observation made indicating the effect of the extract on progressive healing of wound. Comparing to standard drug betadine the bark extract showed faster healing in terms of diameter of wound which was statistically signified.

Conclusion: From the study, $S$. indica proved its wound healing potential of the plant extract which is due to the bioactive compounds, and thus the study supports local folklore practitioners and tribal people for the use of the plant in different ailments. The extracts of $S$. indica are used in traditional medicines for the treatment of skin diseases, rheumatism, cough, and to kill head lice. The present investigation adds to the existing knowledge in the field of therapeutic medicine and may even become the base for the development of herbal based gel formulations or ointments for treating wounds and thereby continuous usage of synthetic drugs; its associated side effects could be avoided.

Keywords: Samadera indica, Wound healing, Albino rats, Methanol extract.

(C) 2019 The Authors. Published by Innovare Academic Sciences Pvt Ltd. This is an open access article under the CC BY license (http://creativecommons. org/licenses/by/4. 0/) DOI: http://dx.doi.org/10.22159/ajpcr.2019.v12i5.32933

\section{INTRODUCTION}

A medicinal plant is any plant, which in one or more of its organs contains active ingredients which can be used for therapeutic purposes or contain foundational compounds that can be used for the synthesis of useful drugs. Medicinal plants have invariably been a rich source of new drugs and many drugs in use today were either obtained from plants or developed using their chemical structure as templates. Various herbal products have been used in the management and treatment of wounds over the past years [1-5].

Samadera indica Gaertner belongs to the family Simaroubaceae with vernacular names Niepa bark tree (English) Lokhandi (Hindi), Kaduhonge (Kannada), Karinjotta, karigotta(Malayalam), and Guchchakaranjah (Sanskrit). It is available in the coastal belt of Dakshina Kannada and Kasaragod districts mainly used by local folklore practitioners and tribal people for various disease treatments. The leaves and bark of the plant are bitter in taste due to glucoside samaderin, yield terpenoids, and flavonoids used against various disorders and skin diseases. The extracts have got antioxidant and antimicrobial activity [6-8]. $S$. indica is an evergreen tree or shrubs up to $10 \mathrm{~m}$ high with stout branches and pale yellow bark. Its propagationis by seeds and flowering and fruiting during April-July.

$S$. indica is commonly found in backwaters and moist deciduous forests and coastal belts of Maharashtra, Kerala, and Karnataka. It is also distributed in the forests of Africa-Madagascar, Myanmar, Papua New Guinea, and Salmon Islands.

Like, the bark is effectively used for the treatment of fever; skin diseases and management of emmenagogue. A decoction of the leaves relieves cough and extract controls head lice. The seeds extract commonly applied as an emetic and purgative; seed oil is applied externally on rheumatic joints and used as a liniment on bruises. A decoction of the leaves is used to kill termites and an infusion of leaves is used as an insecticide.

The main objective of the present study is to evaluate the wound healing properties of methanolic bark extract of $S$. indica.

\section{MATERIALS AND METHODS}

\section{Collection of sample}

S. indica plant was identified by Dr. Rama Bhat P., specimens samples were collected, and herbarium was prepared and deposited with No. ALCMB 05/2015. The bark samples were collected from the forests of Kasaragod district, Kerala state, India, during the month of November 2015, allowed to shade dry for a week. It was then kept in a hot air oven at $60^{\circ} \mathrm{C}$ for $24-48 \mathrm{~h}$ until it was dried completely, make it coarsely powdered and stored in a closed container for further use. 
Preparation of methanolic extract

The coarse powder of the bark ( $25 \mathrm{~g}$ ) was extracted by soxhlation process using $150 \mathrm{ml}$ methanol. This was followed by distillation and the extract obtained was used for wound healing activity.

\section{Experimental animals}

A total of 18 healthy albino rats of four each with an average weight of 150-200 gm were selected randomly for the study which was divided into three groups.

\section{Ointment preparation}

Emulsifying wax and liquid paraffin were heated up to $70-75^{\circ} \mathrm{C}$ and stirred until a uniform mass was obtained. The extracts were incorporated into the ointment base and the composition of the ointment base and the ointment formulations are given in Table 1.

\section{Grouping}

The grouping of the animals for this study will be control, standard, and trial which contain a minimum of six rats in each. Animals in each group were kept in separate cages after weighing and labeling with picric acid stain for their individual identity. The animals were fed with standard laboratory diet and drinking water. The grouping of the animals for the present experiment is shown in Table 2.

\section{Excision wound healing method}

The wound model chosen for the present study was excision wound [9]. Selected animals were starved $12 \mathrm{~h}$ before wounding, anesthetized using diethyl ether in aseptic conditions. A circular patch of fullthickness skin $\left(500 \mathrm{~mm}^{2}\right)$ was cut away from a pre-determined area on the dorsal thoracic region. The animals were housed separately as grouped. The methanolic extract in simple ointment base as mentioned above and betadine ointment were applied on the wound once a day for 20 days starting from the day of wounding. The percentage of wound closure was observed on $1^{\text {st }}, 4^{\text {th }}, 8^{\text {th }}, 12^{\text {th }}$, and $16^{\text {th }}$ post-wounding day by modifying the method of Madhavan et al. [10].

To monitor the changes in the wound and wound shape, the wound margins were traced on thin, transparent polythene sheet which was again retraced on millimeters scale graph paper on the day of wounding ( 0 day) and were followed until complete wound healing.

The experiment was started after obtaining the Institutional Ethical Committee consent.

Statistical analysis

The results of the present experiment were subjected to statistical analysis such as mean, standard deviation, and ANOVA. The data were

Table 1: Composition of the ointment base

\begin{tabular}{ll}
\hline Ingredients & Quantity (\%) \\
\hline Emulsifying wax & 60 \\
Liquid paraffin & 45 \\
Extract & 5 \\
\hline
\end{tabular}

Table 2: The groupings of the animals for the study

\begin{tabular}{llll}
\hline Groups & Drug used & Method & $\begin{array}{l}\text { Number } \\
\text { of rats }\end{array}$ \\
\hline G-1 (control-1) & Natural recovery & $\begin{array}{l}\text { Excision } \\
\text { wound } \\
\text { technique } \\
\text { by Morton } \\
\text { and Malone. }\end{array}$ \\
& & 6 \\
& & " “ & 6 \\
G-2 (Standard) & Betadine ointment & 6 \\
G-3 (Trial drug) & $\begin{array}{l}\text { Methanolic bark } \\
\text { extract } \\
\text { (ointment formulation) }\end{array}$ & \\
\hline & & & \\
\hline
\end{tabular}

statistically analyzed with repeated measures of ANOVA test and multiple comparison procedures test by InStat software. The result was assessed statistically in different aspects for the better understanding such as comparison within group and between groups. Each group wound closure diameter is assessed at $4^{\text {th }}$ day, $8^{\text {th }}$ day, $12^{\text {th }}$ day, and $16^{\text {th }}$ day. The results of wound healing experiment are expressed as a mean \pm standard deviation.

\section{RESULTS}

The progress of wound healing was noted from the $4^{\text {th }}$ day of the experiment until the completion, where on a $16^{\text {th }}$ day full healing was observed (Plate 1).

\section{Mean wound closure observed at different intervals of day in three} groups

Control

As it does not receive any drug, the $4^{\text {th }}$-day wound mean diameter was $236.5 \pm 6.28$, the $8^{\text {th }}$ day the wound mean diameter was $205.0 \pm 2.51$, $12^{\text {th }}$-day wound mean diameter was $168.83 \pm 3.71$, and $16^{\text {th }}$ - day wound mean diameter was $60.5 \pm 10.36$.

\section{Standard drug (betadine ointment)}

As for the group received the standard drug (betadine ointment) for wound healing, $4^{\text {th }}$-day wound mean diameter was $228.0 \pm 8.9$, the $8^{\text {th }}$ day the wound mean diameter was $181.83 \pm 6.654$, the $12^{\text {th }}$ day the wound mean diameter was $130.33 \pm 10.33$, and $16^{\text {th }}$ day the wound mean diameter was $44.83 \pm 7.08$. Hence, there was a marked decrease in wound diameter with every point of time the observation made.

\section{Test drug (methanolic bark extract)}

As for the group received test drug (methanolic bark extract) for wound healing, $4^{\text {th }}$-day wound mean diameter was $208.0 \pm 3.521$, the $8^{\text {th }}$ day the wound mean diameter was $160.66 \pm 7.89,12^{\text {th }}$-day wound mean diameter was $87.5 \pm 5.8$, and $16^{\text {th }}$-day wound mean diameter was $22.5 \pm 5.12$. Thus, there was a marked decrease in wound diameter with every point of time the observation made indicating the effect of the extract on progressive healing of the wound (Table 3).

\section{DISCUSSION}

Medicinal plants have invariably been a rich source of new drugs and many drugs in use today were either obtained from plants or developed using their chemical structure as templates [1]. Pharmacology is the branch of medicine and biology concerned with the study of drug action, where a drug can be broadly defined as any manmade, natural, or endogenous (from within body) molecule which exerts a biochemical
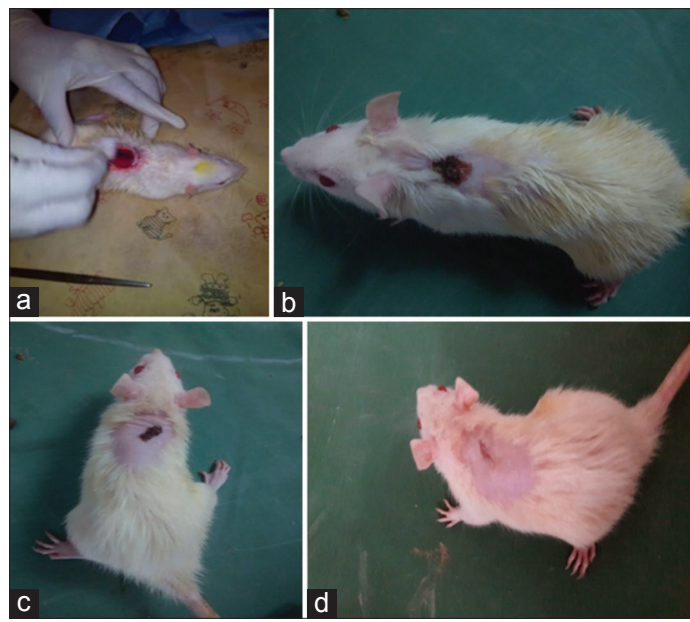

Plate 1: Different stages of wound healing - (a) $1^{\text {st }}$ day, (b) $8^{\text {th }}$ day, (c) $12^{\text {th }}$ day, and (d) $16^{\text {th }}$ day 
Table 3: Mean wound closure and SD measured at different intervals of days in three groups

\begin{tabular}{|c|c|c|c|c|c|c|c|}
\hline \multirow[t]{2}{*}{ Groups day } & \multirow[t]{2}{*}{ Mean } & \multirow{2}{*}{$\begin{array}{l}\text { Standard } \\
\text { deviation }\end{array}$} & \multirow[t]{2}{*}{ Standard error } & \multicolumn{2}{|c|}{$95 \%$ confidence interval for mean } & \multirow[t]{2}{*}{ Minimum } & \multirow[t]{2}{*}{ Maximum } \\
\hline & & & & Lower bound & Upper bound & & \\
\hline $4^{\text {th }}$ day & 236.5000 & 6.28490 & 2.56580 & 229.9044 & 243.0956 & 228.00 & 242.00 \\
\hline Normal control $12^{\text {th }}$ day & 168.8333 & 3.71035 & 1.51474 & 164.9396 & 172.7271 & 164.00 & 174.00 \\
\hline $16^{\text {th }}$ day & 60.5000 & 10.36822 & 4.23281 & 49.6192 & 71.3808 & 41.00 & 71.00 \\
\hline Total & 167.7083 & 68.09551 & 13.89994 & 138.9541 & 196.4625 & 41.00 & 242.00 \\
\hline $4^{\text {th }}$ day & 228.0000 & 8.96660 & 3.66060 & 218.5901 & 237.4099 & 219.00 & 240.00 \\
\hline $8^{\text {th }}$ day & 181.8333 & 6.64580 & 2.71314 & 174.8590 & 188.8077 & 174.00 & 189.00 \\
\hline Standard drug $12^{\text {th }}$ day & 130.3333 & 10.36661 & 4.23215 & 119.4542 & 141.2124 & 116.00 & 142.00 \\
\hline $16^{\text {th }}$ day & 44.8333 & 7.08284 & 2.89156 & 37.4003 & 52.2663 & 38.00 & 55.00 \\
\hline Total & 146.2500 & 69.88764 & 14.26576 & 116.7390 & 175.7610 & 38.00 & 240.00 \\
\hline $4^{\text {th }}$ day & 208.0000 & 3.52136 & 1.43759 & 204.3046 & 211.6954 & 202.00 & 212.00 \\
\hline $8^{\text {th }}$ day & 160.6667 & 7.89092 & 3.22146 & 152.3857 & 168.9477 & 151.00 & 172.00 \\
\hline Test drug $12^{\text {th }}$ day & 87.5000 & 5.82237 & 2.37697 & 81.3898 & 93.6102 & 81.00 & 95.00 \\
\hline $16^{\text {th }}$ day & 22.5000 & 5.12835 & 2.09364 & 17.1181 & 27.8819 & 16.00 & 30.00 \\
\hline Total & 119.6667 & 72.36181 & 14.77079 & 89.1110 & 150.2224 & 16.00 & 212.00 \\
\hline
\end{tabular}

SD: Standard deviation

and/or physiological effect on the cell, tissue, organ, or organism; especially medicinal substances obtained from plants used as drugs. The medicinal values of the plants lie in bioactive phytochemical constituents that produce definite physiological action on the human body.

The present study is to understand the pharmacological aspects of $S$. indica, belongs to the family Simaroubaceae which is a locally available medicinal plant mainly used by local folklore practitioners and tribal peoples for various disease treatments. Viswanad et al. [7] reported the preliminary phytochemical analysis of the methanolic leaf extract of $S$. indica revealed the presence of alkaloids, tannins, phenolic compounds, triterpenes, carbohydrates, steroids, proteins, and flavonoids and suggested that the $S$. indica is a bitter plant and the bitterness is due to the presence of quassinoids. Quassinoids is a triterpenoid responsible for a wide variety of biological activities. Deepa et al. [8] undertaken qualitative and quantitative phytoconstituents of methanolic and aqueous extracts from bark, fruit, and leaf of $S$. indica exhibited the presence of major biomolecules. Raja and Ravindranath [11] reported the chemical and pharmaceutical constituents of $S$. indica.

The study design has numerical data of wound closure diameter of 18 albino rats which are equally divided into three groups, taken from normally distributed population. Hence, the size of the individual group was similar and groups were independent. Hence, ANOVA test was conducted to compare the effect of $S$. indica plant in excision wounds made using scalpel and depilator.

The acute toxicity studies of the methanolic leaf extract of $S$. indica were reported by Viswanad et al. [7] and all the animals tolerated the maximum test doses of the extract, as there were no clinical signs of toxicity or mortality of the animal's extract offers no potential ill effects to animals. Wound healing process consists of different phases such as granulation, collagenation, collagen maturation, and scar maturation which are concurrent but independent to each other. Biological activities in the skin are due to its interaction with various binding proteins. In the tissue repairing, inflammatory cells promote the migration and proliferation of endothelial cells leading to neovascularization of connective tissue cells which synthesize extracellular matrices including collagen resulting reepithelialization of wounded tissue [12]. The present study on the wound healing activity of methanolic bark extract excision wound animal model on the albino rats revealed that the drug extract affects the rate of wound contraction significantly as compared to the standard drug betadine. The above finding provides an insight into the usage of $S$. indica bark in traditional treatment of wounds, skin diseases. On the other hand, Singh et al. [13] revealed that ethanolic leaf extract of Elephantopus scaber treated animals, the rate of wound contraction on day 16, skin breaking strength and weight of the granulation tissue on that day 10 was $92.4 \% 380 \mathrm{~g}$ and $67.67 \mathrm{mg} / 100 \mathrm{~g}$, respectively. There are few earlier reports which support the present result [14-17]. Kodati et al. [18] experimented with methanolic root extracts of Plumbago zeylanica on rats, $10 \%(\mathrm{w} / \mathrm{w})$ extract ointment treated groups showed significant wound healing from day six onward. Complete healing was noted on $16 \pm 2$ days, whereas control group animals took more than $20 \pm 2$ days. Babu et al. [19] reported wound contraction of $97.6,95.2$, and $96.2 \%$, respectively for std, aqueous, and alcohol extract treated animals in an experiment using leaf extracts of Wattakaka volubilis on albino rats with framycetin sulfate cream as standard. Similarly, Garg and Paliwal [20] used aqueous and ethanolic leaf extracts of Ficus benghalensis in wound healing experiments using $10 \%$ ointment base IP placebo as standard. Ethanolic extract showed significant $(\mathrm{p}<0.001)$. The ethanolic extract showed wound healing in 17.16 days whereas the aqueous extract was in 18.33 days as compared with 21.50 days of control. Similar results even reported using extracts of Ficus spp. later by Chowdhary et al. [21].

Matadeen et al. [16] administered a single dose of alcoholic extract of Nyctanthes arbortristis orally to Wistar rats to study the wound healing effect and its effect in dexamethasone suppressed wound healing. The epithelization and wound contraction in case of excision wound showed significant $(\mathrm{p}<0.001)$ with dexamethasone-treated group. Chandra et al. [17] studied that the wound healing activity of methanolic and ethyl acetate extract of Caesalpinia bonducella and Cyclea peltata in PEG base was applied to wounds in diabetically induced rats. They found moderate granulation with marked epithelial enclose and moderate hyperplasia in groups treated with high dose $(100 \mathrm{mg} / \mathrm{kg} \mathrm{BW})$ of the methanolic extract of aerial part of $C$. peltata and root of $C$. bonducella. The wound healing was found to be statistically significant. They concluded that therapeutic medicine may even become the base for the development of herbal based gel formulations or ointments for treating wounds in diabetic patients and thereby continuous usage of synthetic drugs, its associated side effects could be avoided. Similar reports were made in some earlier studies too $[4,22,23]$.

On comparing the treatment effects as per the ANOVA, F value obtained for normal control was 746.651, for standard control 524.108, and for test control F value found to be 1183.974 . Hence, there is a statistically significant difference in the efficacy of drugs in the closure of wound among the various groups at the interval of $4^{\text {th }}-16^{\text {th }}$ day, where $p<0.0001$.

The group which received the test drug for wound healing the on the $4^{\text {th }}-8^{\text {th }}$ day, $12^{\text {th }}$ day, and $16^{\text {th }}$ day shows that there is a high significant decrease in mean diameter with every point of observation made. 
The standard drug on the $4^{\text {th }}-8^{\text {th }}$ day, $12^{\text {th }}$ day, and $16^{\text {th }}$ day showed a decrease in wound diameter. The statistical data proves that the test drug is more effective on the $4^{\text {th }}-8^{\text {th }}$ day, $12^{\text {th }}$ day, and $16^{\text {th }}$ day than the standard drug used and there was a significant difference $(p>0.001)$ in wound diameter which was observed.

The wound healing properties of $S$. indica may be attributed to the phytoconstituents present in the plant, and quick process of wound healing could be a function of either the individual or the additive effects of the phytoconstituents.

\section{ACKNOWLEDGMENT}

The authors are grateful to the Management of Alva's Education Foundation, Moodbidri, Karnataka, for providing financial support to the senior author in the form of a minor research grant.

\section{AUTHORS' CONTRIBUTIONS}

This work was carried out in collaboration between all authors. Author RBP designed the study, supervised the work, managed the analyses of the study, wrote the first draft of the manuscript, and edited the manuscript. Authors DPR carried out all laboratory work, practical work, wrote the protocol, and literature search. Author RRS designed the animal experiment and observed the study. All authors read and approved the final manuscript.

\section{CONFLICTS OF INTEREST}

The authors declare that there are no conflicts of interest.

\section{REFERENCES}

1. Ajaiyeoba EO, Abiodun OO, Falade MO, Ogbole NO, Ashidi JS, Happi CT, et al. In vitro cytotoxicity studies of 20 plants used in Nigerian antimalarial ethnomedicine. Phytomedicine 2006;13:295-8.

2. Raina R, Parwez S, Verma PK, Pankaj NK. Medicinal plants and their role in wound healing. Online Vet J 2008;3:21.

3. Krishnaiah D, Devi T, Bono A, Sarbatly R. Studies on phytochemical constituents of six Malaysian medicinal plants. J Med Plants Res 2009;3:67-72

4. Farahpour MR, Habibi M. Evaluation of the wound healing activity of an ethanolic extract of Ceylon cinnamon in mice. Vet Med 2012;57:53-57.

5. Barreto RS, Albuquerque-Júnior RL, Araújo AA, Almeida JR, Santos MR, Barreto AS, et al. A systematic review of the woundhealing effects of monoterpenes and iridoid derivatives. Molecules 2014; 19:846-62.

6. Viswanad V, Aleykutty NA, Jayakar B, Zacharia SM, Thomas L. Development and evaluation of antimicrobial herbal formulations containing the methanolic extract of Samadera indica for skin diseases. J Adv Pharm Technol Res 2012;3:106-11.

7. Viswanad V, Aleykutty NA, Jaykar B, Subin MZ, Litha T. Studies on antimicrobial and antioxidant activity of methanolic extract of Samadera indica. Int J Pharm Sci Rev Res 2011;11:59-64.

8. Deepa PR, Chaithanneya R, Ramabhat P. Phytochemical properties and antimicrobial activities of leaf, bark, fruit extracts and silver nanoparticles of Samadera indica Gaertner. Eur J Biotechnol Biosci 2015;3:30-7.
9. Morton JJ, Malone MH. Evaluation of vulneray activity by an open wound procedure in rats. Arch Int Pharm Thér 1972;196:117-26.

10. Madhavan V, Tomar AT, Murali A, Yoganarasimhan SN. Wound healing and antipyretic activity of stem bark of Wrightia tinctoria. J Trop Med Plants 2006;7:69-71.

11. Raja S, Ravindranath K. Chemical and pharmacological aspects of Samadera indica (Simaroubaceae): An overview. Int J Biol Pharm Res 2014;5:958-63.

12. Agarwal PK, Singh A, Gaurav K, Goel S, Khanna HD, Goel RK, et al. Evaluation of wound healing activity of extracts of plantain banana (Musa sapientum var. paradisiaca) in rats. Indian J Exp Biol 2009; 47:32-40.

13. Singh SD, Krishna V, Mankani KL, Manjunatha BK, Vidya SM, Manohara YN. Wound healing activity of the leaf extracts and deoxyelephantopin isolated from Elephantopus scaber. Indian J Pharmacol 2005;37:238-42.

14. Umachigi SP, Jayaveera KN, Ashok KC, Kumar GS, Vrushabendra SB, Kishore KD. Studies on wound healing properties of Quercus infectoria. Trop J Pharm Res 2008;7:913-9.

15. Barua CC, Talukdar A, Begum SA, Sarma DK, Fathak DC, Barua AG, et al. Wound healing activity of methanolic extract of leaves of Alternanthera brasiliana Kuntz using in vivo and in vitro model. Indian J Exp Biol 2009;47:1001-5.

16. Matadeen B, Saxena RC, Neetu A, Gourav S, Rahul S, Apte KG. Wound healing activity of alcoholic extract of Nyctanthes arbortristis L. in wistar rats. Int J Pharm Pharm Sci 2011;3:253-5.

17. Chandra SJ, Murthy SM, Ramesh R. Evaluation of the wound healing activity of Caesalpinia bonducella and Cyclea peltata extracts in experimentally induced diabetic rats. Int J Pharm Pharm Sci 2017;9:211-7

18. Kodati DR, Goud PR, Burra S, Galipelly SK. Evaluation of wound healing activity of methanolic root extract of Plumbago zeylanica in wistar albino rats. Asian J Plant Sci Res 2011;1:26-34.

19. Babu VL, GoravanakollaA, MuraliA, MadhavanA, Yoganarasimhan SN Wound healing activity of the leaves of Wattakaka volubilis (L. f.) Stapf (Asclepiadaceae). Int J Appl Res Nat Prod 2012;5:23-9.

20. Garg VK, Paliwal SK. Wound-healing activity of ethanolic and aqueous extracts of Ficus benghalensis. J Adv Pharm Technol Res 2011;2:110-4.

21. Chowdhary N, Mohanjith K, Amarjeeth S, Bilmesh K. Wound healing activity of aqueous extracts of Ficus religiosa and Ficus benghalensis leaves in rats. Indian J Res Pharm Biotechnol 2014;2:1071-81.

22. Imam SA, Saroj KR, Niranjan S, Uma SS, Ranju S. Woundb healing activity of Kaempferia rotunda leaf extract. Int J Curr Microbiol Appl Sci 2013;2:74-8

23. Marume A, Matope G, Katsande S, Khoza S, Mutingwende I, Mduluza T, et al. Wound healing properties of selected plants used in ethnoveterinary medicine. Front Pharmacol 2017;8:544

1. Sharma G, Lamichhane G. A review of plant based medicine in treatment of urolithiatic disorder. Pharm Innov J 2017;6:8-12

2. Anbu J, Suman S, Swaroop KS, Kumar SL, Satheesh SK, Kannadhasan R. Antiurolithiatic activity of ethyl acetate root extract of Ichnocarpus frutescens using ethylene glycol induced method in rats. J Pharm Sci Res 2011;3:1182-9.

3. Poojar B, Ommurugan B, Adiga S, Thomas H. Evaluation of antiurolithiatic property of ethanolic extract of fennel seeds in male wistar albino rats. Asian J Pharm Clin Res 2017;10:313.

4. Gürocak S, Küpeli B. Consumption of historical and current phytotherapeutic agents for urolithiasis: A critical review. J Urol 2006;176:450-5.

5. Peres A, Santos F 